\title{
SPECTRUM AND FREQUENCY OF NK CELL RECEPTOR GENES AMONG CYSTIC FIBROSIS PATIENTS
}

\author{
Danuta Zastavna ${ }^{1,2}$ \\ zastavna.d@ihp.lviv.ua \\ Kateryna Sosnina ${ }^{1}$ \\ katja.sosnina@gmail.com \\ Oresta Terpyliak ${ }^{1}$ \\ oresta.terp@gmail.com \\ Halyna Makukh ${ }^{1}$ \\ makuh.h@ihp.lviv.ua \\ Bogdan Tretiak \\ irynej@ukr.net \\ Ludmyla Bober \\ Western Ukrainian Specialized Children's Medical Centre \\ 27 Dnisterska str., Lviv, Ukraine, 79008 \\ luda.bober@gmail.com \\ Miroslav Tyrka \\ mtyrka@prz.edu.pl \\ ${ }^{1}$ SI "Institute of Hereditary Pathology Ukrainian \\ National Academy of Medical Sciences" \\ 31-a Lysenko str., Lviv, Ukraine, 79008 \\ ${ }^{2}$ Department of Biotechnology and Bioinformatics \\ Faculty of Chemistry \\ Rzeszow University of Technology \\ 6 Al. Powstańców Warszawy, Rzeszow, Poland, 35-959
}

\begin{abstract}
Aim - to establish and analyze the spectrum of KIR genes in people with a confirmed diagnosis of Cystic fibrosis (CF), homozygote of F508del mutation of the CFTR gene for understanding the genetic predisposition of congenital immunity key part functioning during $\mathrm{CF}$.

Materials and Methods. Examined 48 people with a confirmed diagnosis of CF, homozygotes of the F508del mutation of the CFTR gene, and 104 practically healthy people without the F508del mutation of the CFTR gene from the control group. The following molecular genetic methods were used: DNA extraction from peripheral blood cells, KIR genotyping by PCR-SSP for the presence or absence of the 14 KIR genes (KIR2DL1, 2DL2, 2DL3, 2DL4, 2DL5, 2DS1, 2DS2, 2DS3, 2DS4, 2DS5, 3DL1, 3DL2, 3DL3, 3DS1).

Results - molecular genetic studies of KIR-genes repertoire in the group of cystic fibrosis patients showed a decrease in the frequency of genes, responsible for activating NK cells receptors. Of the five examined NK cell activation genes, one gene was completely absent, namely 2DS4, and another (2DS1) was detected in only 3 of 48 patients examined, which was $6.25 \%$, and this figure is significantly lower in comparison with the control group $\left(\chi^{2}=4.801, \mathrm{p}<0.05\right)$. Regarding the genes of NK-cell inhibitory receptors, all investigated genes were detected in the study group ( 8 in general). By detection frequency, they mostly correspond to the control group, with the exception of the 2DL3 gene, found in patients with CF with a significantly lower frequency $\left(\chi^{2}=11.97, \mathrm{p}<0.005\right)$.

Conclusion - for the first time in the group of patients with CF, a study was performed on the frequency and spectrum of KIR-genes, responsible for NK cell receptors. Reducing the frequency of activation NK cell receptor genes in patients with CF can lead to a weakening of congenital immunity and the severity of infectious processes during CF.

Keywords: NK cells, KIR - killer cell immunoglobulin-like receptor, KIR genes, Cystic fibrosis.
\end{abstract}




\section{Introduction}

NK (Natural Killers) - cytotoxic cells, whose role is to recognize and eliminate foreign antigens. NK cells are directed against pathogenic infections and/or infected and transformed cells of their own organism. This is one of the key elements of innate cellular immunity. However, highlighting specific cytokines (in particular immune interferon) and thereby affecting the acquired humoral immunity, they also play an important immunoregulatory function in the body [1, 2].

Functional activity of NK cells is thoroughly regulated by a complex of receptors that are located on the cell surface. These receptors are divided into activating and inhibitory [3]. When activating receptors are dominant, the NK cell performs its cytotoxic activity in identifying and eliminating target cells, and when inhibitory receptors are included, the cytotoxic activity of the NK cells is blocked and no lysis of target cells occurs or significantly slows down [4]. Currently at least five major groups of natural killer structural receptors are known, among which the most studied are immunoglobulin-like receptors - KIR (killer cell immunoglobulin-like receptor) [3, 5, 6]. KIRs are transmembrane glycoproteins with two or three extracellular immunoglobulin-like domains (KIR2D and KIR3D, respectively) and a long (L) or short (S) cytoplasmic tail. Receptors with L-tail carry out an inhibitory signal, and with S-tail - activating [7, 8].

The KIR genes are polymorphic and highly homologous and they are found in a cluster on chromosome 19q13.4 within the $1 \mathrm{Mb}$ leukocyte receptor complex $(L R C)$. Currently, 18 KIR genes have been identified. The KIRs gene repertoire is characterized by high interindividual polymorphism: only $2 D L 4,3 D L 2$ and $3 D L 3$ genes and several non-expressed genes are always present, the presence of other genes is not unambiguous [8-10]. This, in turn, causes a large heterogeneity of $K I R-$ haplotypes. KIR - haplotypes are divided into two groups: A and B, which differ from each other, above all, in the total number of genes, coding activating KIR receptors. Group A haplotypes contain only one KIR2DS4 activating gene, while haplotypes of group B contain various combinations of KIR activation genes, namely KIR2DS1, KIR2DS2, KIR2DS3, KIR2DS4, KIR2DS5, KIR3DS1 [6, 11].

Cystic fibrosis (CF) is the most common monogenic autosomal recessive disease of the european race, the carrier frequency of the mutation, responsible for $\mathrm{CF}-1: 2500$ [12]. The cause of the disease is the mutation in the gene, responsible for the synthesis of the chlorine transport channel CFTR (cystic fibrosis transmembrane conduction regulator). The so-called major, most common mutation, which in most cases is associated with the early appearance of the first clinical signs of CF and with a particularly severe course of the disease, is the mutation of the F508del of the CFTR gene [13].

The greatest threat to life in patients with CF is caused by infections of the upper respiratory tract, which are massively multiplied in the good environment, made due to violation of the mucus outflow [14]. An accurate prognostic assessment of the treatment outcome is not possible, even in cases, where the type of mutation is accurately determined, an identification of the infectious agent is carried out and adequate therapy, including antimicrobial, is performed. It is obvious, that the immunological features of the patient with CF, in particular the state of his/her innate immunity, in particular the cellular component, which is represented by NK cells, plays a role here. All of the above has led us to study the genetically determined cytotoxic activity of natural killers in individuals with CF.

The aim of the work was to establish and analyze the spectrum of $K I R$ genes in people with a confirmed diagnosis of CF, homozygote of F508del mutation of the CFTR gene for understanding the genetic predisposition of congenital immunity key part functioning during $\mathrm{CF}$.

\section{Material and Methods}

The research material was DNA, isolated from the peripheral blood of 48 people ( 27 women and 21 men aged 0 to 30 years) with a confirmed diagnosis of CF, homozygotes of the F508del mutation of the CFTR gene, which were screened at the Institute of Hereditary Pathology of the National Academy of Medical Sciences of Ukraine and were treated in the inpatient unit of the Western Ukrainian Specialized Child Medical Center and 104 practically healthy people (59 women and 45 men aged 0 to 30 years) without of the F508del mutation of the CFTR gene from the control group.

KIR genotyping was performed in 2019. The biological material was taken from the DNA bank SI "Institute of Hereditary Pathology Ukrainian National Academy of Medical Sciences" for the last 10 years. 
These studies were considered at a meeting of the Committee on Bioethics SI «Institute of Hereditary Pathology of the National Academy of Medical Sciences of Ukraine». (Protocol No. 63, 09.03.2020). The members of the Committee agreed that the materials, provided for the examination, were scientifically substantiated.

The information letters contain the consent of all patients and parents / guardians of the children to use their biological material for research. All measures, concerning patients' health, respect for human rights, human dignity and moral and ethical standards are taken into account in accordance with the principles of the Declaration of Helsinki and the European Convention on Human Rights.

DNA from peripheral blood lymphocytes was isolated by the solution method [15]. The KIR receptor genes were modeled, using polymerase chain reaction with allele specific primers (PCR-SSP, polymerase chain reaction with s sequence-specific primers) [16]. The primers were synthesized by the company "Sigma"(Germany). The allele characterization was based on the presence or absence of a PCR product that was recorded, using $2 \%$ agarose gel electrophoresis, stained with bromine acetic acid in UV light at a wavelength of $302 \mathrm{~nm}$.

The statistical analysis of data was carried out, following methods: gene frequencies and the theoretically expected distribution of genotypes were calculated, using contingent tables $2 \times 2$ by the Pearson $\mathrm{c} 2$ criterion calculation. The verification of statistical hypotheses was carried out at the level of significance $p \leq 0.05$.

\section{Results and Discussion}

The presence/absence of $13 \mathrm{KIR}$ genes in a group of 48 people with a confirmed diagnosis of CF, homozygote for the F508del mutation of the CFTR gene was analyzed. The range of KIR genes in the study group was compared with that in a control, consisting of 104 healthy individuals without the carrier of mutations in the TRBM gene. The results of genotyping are presented in Table 1.

In the control group, all 13 detected KIR genes were present. Their frequency ranged from $10.58 \%$ (for the $2 D S 4$ gene) to $100 \%$ (for structural genes $2 D L 4,3 D L 2$ and $3 D L 3$ ). As can be seen from the results presented, the KIR genes of the inhibitory receptors were more frequent in the control group than the activation receptor genes. The results we get are in common with the results of other researchers $[7,11,17,18]$. It should be noted, that the primary in evolutionary point of view are the inhibitory receptors of NK cells, whose role was to inhibit the cytotoxic activity of natural killer cells, in particular, with regard to the cells of their own organism. And as the accumulation of foreign antigens in the environment, including disease-causing infections, evolutionarily increased the number of activating receptors $[19,20]$. This can be explained, in particular, by the fact that the Japanese [21], living in a more or less isolated world, predominate the haplotype of the group A, which is characterized by the presence of only one activation gene KIR2DS4, while the Australian aborigines migrated from different continents, on the contrary, predominate the haplotype of the group B with the presence of various combinations of many (up to 6) genes of activation KIRs [22]. The combination of activating and inhibitory NK receptor cells, obviously, also depends on the risk of infecting an organism with a particular infectious factor.

In the continuation of the above, as can be seen from Table 1 and Fig. 1, the spectrum of $K I R$-genes in the studied group of cystic fibrosis patients is calculated by the presence of 12 of the 13 studied genes. First of all, it should be noted, that of the five investigated genes of NK cell activation receptors, one gene was completely absent, namely $2 D S 4$, and another $(2 D S 1)$ was detected in only 3 of the 48 patients investigated, which was $6.25 \%$, and this indicator is significantly lower than the control group $\left(\chi^{2}=4.801, p<0.05\right)$. Regarding the genes of NK-cell inhibitory receptors, all investigated genes were detected in the study group ( 8 in general). By frequency, they mostly correspond to the control group, with the exception of the $2 D L 3$ gene. $37.5 \%$ of patients with CF are carriers of the $2 D L 3$ inhibitor gene at a control rate of $67.31 \%$. The statistical calculations showed a significantly lower frequency of the $2 D L 3$ gene in the investigated group, compared to the control with the values $\chi^{2}=11.97, p<0.005$. 
Table 1

Distribution and frequency of $K I R$ genes in a group of people, diagnosed with CF

\begin{tabular}{|c|c|c|c|c|c|c|}
\hline \multirow{2}{*}{ KIR gene } & \multicolumn{2}{|c|}{ Control group, $n=104$} & \multicolumn{2}{|c|}{ Patients with cystic fibrosis, $n=48$} & \multirow{2}{*}{$\chi^{2}$} & \multirow{2}{*}{$\mathbf{P}$} \\
\hline & $\mathbf{n}$ & $\%$ & $\mathbf{n}$ & $\%$ & & \\
\hline $2 D L 1$ & 96 & 92.31 & 45 & 93.75 & 0.102 & $>0.05$ \\
\hline $2 D L 2$ & 60 & 57.69 & 25 & 52.08 & 0.419 & $>0.05$ \\
\hline $2 D L 3$ & 70 & 67.31 & 18 & 37.50 & 11,97 & $<0.05$ \\
\hline $2 D L 4$ & 104 & 100 & 47 & 97.92 & 2.181 & $>0.05$ \\
\hline $2 D L 5$ & 38 & 36.54 & 17 & 35.42 & 0.018 & $>0.05$ \\
\hline $3 D L 1$ & 96 & 92.31 & 43 & 89.58 & 0.312 & $>0.05$ \\
\hline $3 D L 2$ & 104 & 100 & 48 & 100.00 & 1 & - \\
\hline $3 D L 3$ & 104 & 100 & 48 & 100.00 & 1 & - \\
\hline $2 D S 1$ & 21 & 20.19 & 3 & 6.25 & 4.801 & $<0.05$ \\
\hline $2 D S 2$ & 37 & 35.58 & 16 & 33.33 & 0.073 & $>0.05$ \\
\hline $2 D S 3$ & 34 & 32.69 & 15 & 31.25 & 0.031 & $>0.05$ \\
\hline $2 D S 4$ & 11 & 10.58 & 0 & 0.00 & 5.473 & $<0.05$ \\
\hline $3 D S 1$ & 34 & 32.69 & 20 & 41.67 & 1.155 & $>0.05$ \\
\hline
\end{tabular}

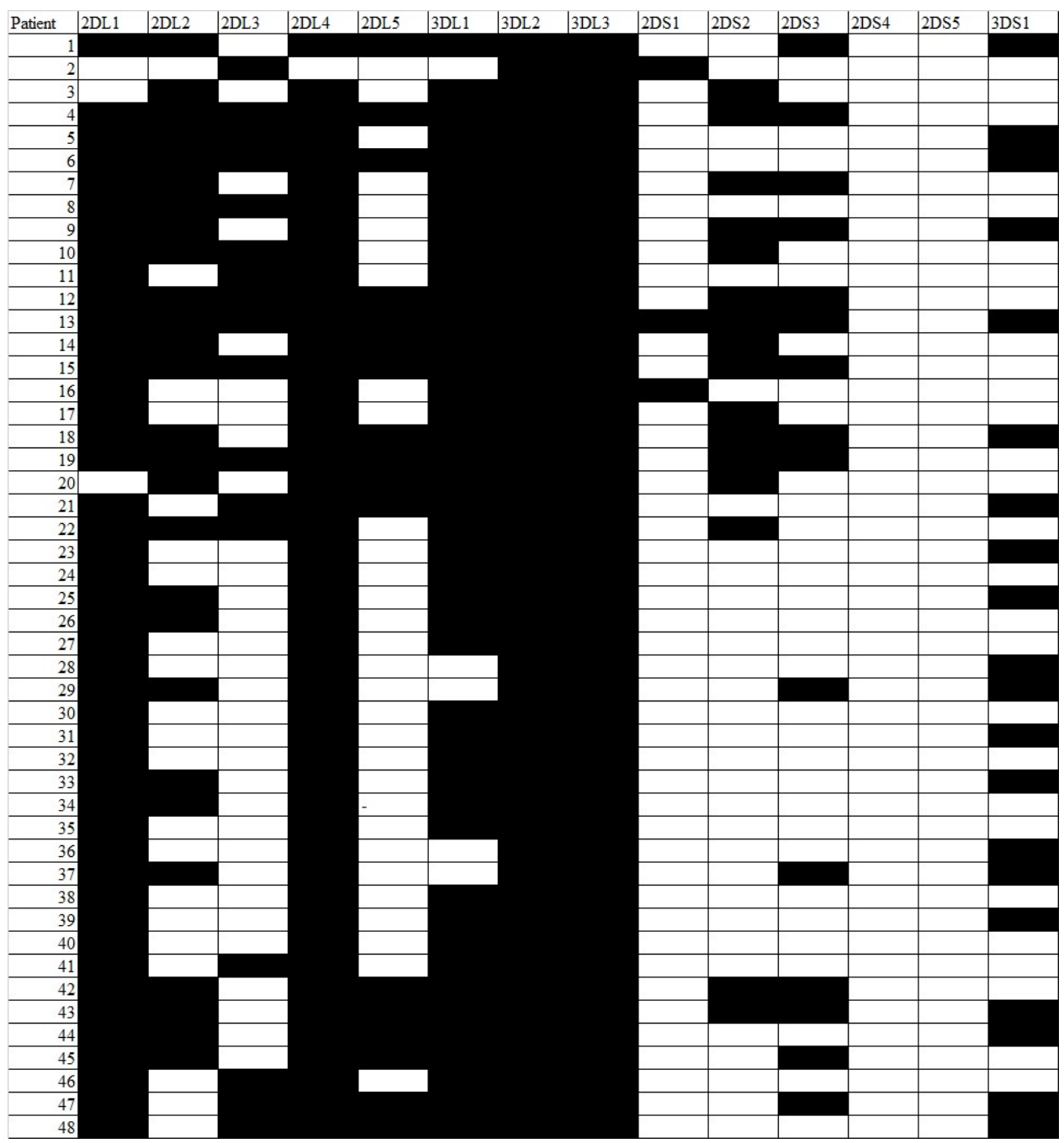

Fig. 1. Spectrum of $K I R$ genes among patients with cystic fibrosis 
Summing up the above results, it is evident, that there is a violation of the spectrum and frequency of KIR genes in a group of patients with a diagnosis of cystic fibrosis. Compared with the control group, patients with CF are characterized by low frequency of genes, responsible for activation NK cell receptors. As CF is accompanied by severe infectious lesions of the upper respiratory tract, the treatment of which is far from always effective, it cannot be ruled out, that the genetically induced weakness of the activating receptor site of natural killer cells is affecting this process. It should be noted, that we did not meet such studies in the literature, but based on literary data, which relate mainly to HIV infection [23-25] and hepatitis C [26-30], it can be concluded, that the more gentle progression of the disease correlates with increased activation of the functional activity of NK cells.

Study limitations. The limitations of our study are the small sample size due to population characteristics.

Prospects for further research. In the future, we plan to expand our research, in particular, we consider it appropriate to include the study of genes of the Major Histocompatibility Complex Class I.

\section{Conclusion}

For the first time in the group of patients with diagnosed cystic fibrosis, the frequency and spectrum of KIR genes, responsible for NK-cell receptors was studied. The results, obtained of KIR-genes repertoire in the group of cystic fibrosis patients, showed a decrease in the frequency of KIR2DS1 and KIR2DS4 $\left(\chi^{2}=4.801, p<0.05\right.$ and $\left.\chi^{2}=5.473, p<0.05\right)$ genes, responsible for activating NK cells receptors. Regarding the genes of NK-cell inhibitory receptors, by detection frequency, they mostly correspond to the control group, with the exception of the 2DL3 gene, found in patients with CF with a significantly lower frequency $\left(\chi^{2}=11.97, p<0.005\right)$. The obtained results indicated a change in the frequency and spectrum of KIR genes in cystic fibrosis patients, compared with the control group towards the reduced frequency of activation NK cells receptor genes. We assume that the established low frequency of genes, responsible for activation NK cell receptors in patients with cystic fibrosis, can lead to a weakening of the primary immunity and the severity of the course of infectious processes in patients with cystic fibrosis.

\section{Conflicts of interest}

This work does not have any of the potential conflicts of interest.

\section{References}

[1] Hamerman, J. A., Ogasawara, K., Lanier, L. L. (2005). NK cells in innate immunity. Current Opinion in Immunology, 17 (1), 29-35. doi: https://doi.org/10.1016/j.coi.2004.11.001

[2] Vivier, E., Ugolini, S. (2011). Natural Killer Cells: From Basic Research to Treatments. Frontiers in Immunology, 2. doi: https://doi.org/10.3389/fimmu.2011.00018

[3] Srivastava, R. M., Savithri, B., Khar, A. (2003). Activating and inhibitory receptors and their role in Natural Killer cell function. Indian Journal of Biochemistry and Biophysics, 40 (5), 291-299.

[4] Malhotra, A., Shanker, A. (2011). NK cells: immune cross-talk and therapeutic implications. Immunotherapy, 3 (10), $1143-$ 1166. doi: https://doi.org/10.2217/imt.11.102

[5] Joyce, M. G., Sun, P. D. (2011). The Structural Basis of Ligand Recognition by Natural Killer Cell Receptors. Journal of Biomedicine and Biotechnology, 2011, 1-15. doi: https://doi.org/10.1155/2011/203628

[6] Carrington, M., Norman, P. (2003). The KIR Gene Cluster. Bethesda (MD): National Center for Biotechnology Information (US). Available at: https://www.ncbi.nlm.nih.gov/books/NBK10135/pdf/Bookshelf_NBK10135.pdf

[7] Omar, S. Y. A., Alkuriji, A., Alwasel, S., Dar, javid A., Alhammad, A., Christmas, S., Mansour, L. (2016). Genotypic diversity of the Killer Cell Immunoglobulin-like Receptors (KIR) and their HLA class I Ligands in a Saudi population. Genetics and Molecular Biology, 39 (1), 14-23. doi: https://doi.org/10.1590/1678-4685-gmb-2015-0055

[8] Campbell, K. S., Purdy, A. K. (2011). Structure/function of human killer cell immunoglobulin-like receptors: lessons from polymorphisms, evolution, crystal structures and mutations. Immunology, 132 (3), 315-325. doi: https://oi.org/10.1111/ j.1365-2567.2010.03398.x 
[9] Wagner, I., Schefzyk, D., Pruschke, J., Schöfl, G., Schöne, B., Gruber, N. et. al. (2018). Allele-Level KIR Genotyping of More Than a Million Samples: Workflow, Algorithm, and Observations. Frontiers in Immunology, 9. doi: https://doi.org/ 10.3389/fimmu.2018.02843

[10] Vilches, C., Parham, P. (2002). KIR: Diverse, Rapidly Evolving Receptors of Innate and Adaptive Immunity. Annual Review of Immunology, 20 (1), 217-251. doi: https://doi.org/10.1146/annurev.immunol.20.092501.134942

[11] Hollenbach, J. A., Nocedal, I., Ladner, M. B., Single, R. M., Trachtenberg, E. A. (2012). Killer cell immunoglobulin-like receptor (KIR) gene content variation in the HGDP-CEPH populations. Immunogenetics, 64 (10), 719-737. doi: https://doi. org/10.1007/s00251-012-0629-x

[12] Scotet, V., Duguépéroux, I., Audrézet, M.-P., Blayau, M., Boisseau, P., Journel, H. et. al. (2008). Prenatal diagnosis of cystic fibrosis: the 18-year experience of Brittany (western France). Prenatal Diagnosis, 28 (3), 197-202. doi: https://doi.org/ $10.1002 /$ pd. 1910

[13] Gamaletsou, M. N., Hayes, G., Harris, C., Brock, J., Muldoon, E. G., Denning, D. W. (2017). F508del CFTR gene mutation in patients with allergic bronchopulmonary aspergillosis. Journal of Asthma, 55 (8), 837-843. doi: https://doi.org/10.1080/ 02770903.2017.1373808

[14] Maurya, N., Awasthi, S., Dixit, P. (2012). Association of CFTR gene mutation with bronchial asthma. Indian Journal of Medical Research, 135 (4), 469-478.

[15] Makukh, H. V., Zastavna, D. V., Tyrkus, M. Y., Tretiak, B. I., Chorna, L. B. (2008). Pat. No. 32044 UA. Method for separation of DNA from leucocytes of peripheral blood. No. u200801896; declareted: 14.02.2008; published: 25.04.2008, Bul. No. 8 .

[16] Vilches, C., Castaño, J., Gómez-Lozano, N., Estefanía, E. (2007). Facilitation of KIR genotyping by a PCR-SSP method that amplifies short DNA fragments. Tissue Antigens, 70 (5), 415-422. doi: https://doi.org/10.1111/j.1399-0039.2007. 00923.x

[17] Norman, P. J., Carrington, C. V. F., Byng, M., Maxwell, L. D., Curran, M. D., Stephens, H. A. F. et. al. (2002). Natural killer cell immunoglobulin-like receptor (KIR) locus profiles in African and South Asian populations. Genes \& Immunity, 3 (2), 86-95. doi: https://doi.org/10.1038/sj.gene.6363836

[18] Flores, A. C., Marcos, C. Y., Paladino, N., Capucchio, M., Theiler, G., Arruvito, L. et. al. (2007). KIR genes polymorphism in Argentinean Caucasoid and Amerindian populations. Tissue Antigens, 69 (6), 568-576. doi: https://oi.org/10.1111/ j.1399-0039.2007.00824.x

[19] Espeli, M., Niederer, H. A., Traherne, J. A., Trowsdale, J., Smith, K. G. (2010). Genetic variation, Fc $\gamma$ receptors, KIRs and infection: the evolution of autoimmunity. Current Opinion in Immunology, 22 (6), 715-722. doi: https://doi.org/10.1016/ j.coi.2010.10.003

[20] Martin, A. M., Freitas, E. M., Witt, C. S., Christiansen, F. T. (2000). The genomic organization and evolution of the natural killer immunoglobulin-like receptor (KIR) gene cluster. Immunogenetics, 51 (4-5), 268-280. doi: https://doi.org/10.1007/ s002510050620

[21] Bao, X., Hou, L., Sun, A., Qiu, Q., Yuan, X., Chen, M. et. al. (2010). Distribution of killer cell immunoglobulin-like receptor genes and 2DS4 alleles in the Chinese Han population. Human Immunology, 71 (3), 289-292. doi: https://doi.org/10.1016/ j.humimm.2009.12.004

[22] Toneva, M., Lepage, V., Lafay, G., Dulphy, N., Busson, M., Lester, S. et. al. (2001). Genomic diversity of natural killer cell receptor genes in three populations. Tissue Antigens, 57 (4), 358-362. doi: https://doi.org/10.1034/j.13990039.2001.057004358.x

[23] Zwolińska, K., Błachowicz, O., Tomczyk, T., Knysz, B., Gąsiorowski, J., Zalewska, M. et. al. (2016). The effects of killer cell immunoglobulin-like receptor (KIR) genes on susceptibility to HIV-1 infection in the Polish population. Immunogenetics, 68 (5), 327-337. doi: https://doi.org/10.1007/s00251-016-0906-1

[24] Garrido-Rodríguez, D., Ávila-Ríos, S., García-Morales, C., Valenzuela-Ponce, H., Ormsby, C., Reyes-Gopar, H. et. al. (2016). Killer cell immunoglobulin-like receptor and human leukocyte antigen gene profiles in a cohort of HIV-infected Mexican Mestizos. Immunogenetics, 68 (9), 703-717. doi: https://oi.org/10.1007/s00251-016-0920-3

[25] Naranbhai, V., de Assis Rosa, D., Werner, L., Moodley, R., Hong, H., Kharsany, A. et. al. (2015). Killer-cell Immunoglobulin-like Receptor (KIR) gene profiles modify HIV disease course, not HIV acquisition in South African women. BMC Infectious Diseases, 16 (1). doi: https://doi.org/10.1186/s12879-016-1361-1 
[26] Kuśnierczyk, P., Mozer-Lisewska, I., Zwolińska, K., Kowala-Piaskowska, A. E., Bura, M., Bereszyńska, I. et. al. (2015). Contribution of genes for killer cell immunoglobulin-like receptors (KIR) to the susceptibility to chronic hepatitis $\mathrm{C}$ virus infection and to viremia. Human Immunology, 76 (2-3), 102-108. doi: https://doi.org/10.1016/j.humimm.2015.01.020

[27] Shan, Z., Huang, J., Liao, Q., Huang, K., Wang, M., Xu, R. et. al. (2018). Association of killer cell immunoglobulin-like receptors with spontaneous clearance of hepatitis $\mathrm{C}$ virus in the Chinese population. Transfusion, 58 (4), $1028-1035$. doi: https://doi.org/10.1111/trf.14527

[28] Podhorzer, A., Dirchwolf, M., Machicote, A., Belen, S., Montal, S., Paz, S. et. al. (2018). The Clinical Features of Patients with Chronic Hepatitis C Virus Infections Are Associated with Killer Cell Immunoglobulin-Like Receptor Genes and Their Expression on the Surface of Natural Killer Cells. Frontiers in Immunology, 8. doi: https://doi.org/10.3389/fimmu.2017.01912

[29] Romero, V., Azocar, J., Zúñiga, J., Clavijo, O. P., Terreros, D., Gu, X. et. al. (2008). Interaction of NK inhibitory receptor genes with HLA-C and MHC class II alleles in Hepatitis C virus infection outcome. Molecular Immunology, 45(9), 24292436. doi: https://doi.org/10.1016/j.molimm.2008.01.002

[30] Montes-Cano, M. A., Caro-Oleas, J. L., Romero-Gómez, M., Diago, M., Andrade, R., Carmona, I. et. al. (2005). HLA-C and KIR Genes in Hepatitis C Virus Infection. Human Immunology, 66 (11), 1106-1109. doi: https://doi.org/10.1016/j.humimm.2006.02.001 